\title{
FAITH-BASED INTERVENTIONS IN THE REINTEGRATION OF DISPLACED BOKO HARAM VICTIMS INTO THE SOCIETY: A REVIEW OF SELECTED LITERATURE
}

\author{
Adebayo Ola Afolaranmi \\ PhD Student \\ Peace and Conflict Studies \\ Lead City University Ibadan, Nigeria
}

Article DOI: https://doi.org/10.36713/epra4986

This article is an excerpt from my dissertation titled "Faith-Based Responses to Displaced Boko Haram Victims: A Case Study of Baptist Churches in Ogbomoso Land, Nigeria" (MPhil diss., Irish School of Ecumenics, Trinity College Dublin, 2016).

\begin{abstract}
Boko Haram insurgency has affected many people in the northeastern part of Nigeria. Many of these victims have migrated to other parts of the country. While some of these people become internally displaced persons (IDPs) in IDP centres or camps, some prefer to migrate to, and live among their ancestral relatives. The latter are referred to as migrated displaced persons. Many faith-based organizations especially churches of the Nigerian Baptist Convention have been making efforts to transform the lives of these displaced people and reintegrate them into the society. The paper reviews some related themes such as terrorism and religious violence, Boko Haram insurgency in Nigeria, jihad, trauma, internally displaced persons, Christian theological bases for humanitarianism, Baptist policy/theological stands on humanitarianism, and religious responses to crisis in transforming lives of displaced people from conflict-affected areas. The paper ends with some recommendations for faith-based organizations and the Nigerian government.

KEYWORDS: Boko Haram, terrorism, conflict transformation, internally displaced persons, migrated displaced persons, faith-based organizations, Nigerian Baptist Convention, Nigeria
\end{abstract}

\section{INTRODUCTION}

The world is full of crisis, conflicts and wars. ${ }^{1}$ These conflicts arise because of various political, economic, religious and other reasons. Some of these conflicts (like the ones cause by Boko Haram, a terrorist group in the northeast Nigeria) have caused many people to become refugees in other countries, while many others have become internally displaced

1 Conflict Barometer 2015, a publication of The Heidelberg Institute for International Conflict Research (HIIK) at the Department of Political Science, University of Heidelberg (Accessed 23 June 2016.

http://www.hiik.de/de/konfliktbarometer/pdf/Conflict Barometer 2015.pdf) analysed disputes, non-violent crises, violent crises, limited wars, and wars in the world in the year 2015 . in their countries. ${ }^{2}$ They are often camped in internally displaced persons' (IDPs) camps or centers where governments, Non-Governmental Organizations (NGOs), faith-based and other humanitarian organizations care for them. There is a unique set of people that have migrated back to their ancestral home in Ogbomoso land in southwestern part of Nigeria. The churches of the Nigerian Baptist Convention, a faith-based organization, are making efforts to transform the lives of these displaced people and reintegrate them into the society. Nonetheless, the Convention and researchers that are members of its churches have not deemed it fit to really study and document the roles of the

2 Branis Knezevic and Seth Olson. "Counseling People Displaced by War: Experiences of Refugees from the Former Yugoslavia." Professional Counselor. Vol. 4, No. 4, 2014. 
Convention and its churches in responding to transforming the lives of the displaced persons. This paper aims at reviewing selected literature on related themes such as: terrorism and religious violence, Boko Haram insurgency in Nigeria, jihad, trauma, internally displaced persons, Christian theological bases for humanitarianism, Baptist policy/theological stand on humanitarianism, and religious responses to crisis in transforming lives of displaced people from conflict-affected areas.

\section{TERRORISM AND RELIGIOUS VIOLENCE}

Scholars do not agree on the definition of terrorism. Nevertheless, terrorism has been described as "the premeditated use or threat to use violence by individuals or subnational groups to obtain a political or social objective through the intimidation of a large audience beyond that of the immediate noncombatant victims." 3 Historically, the word terrorism was first used during the French Revolution (1789-1799) when it was used to portray the government. Nonetheless, by 1848 , people used the word to describe vicious rebels. The connotation of terrorism changed to depict the forceful acts of some organized sets of people, like labor associations, revolutionaries, nationalistic groups, and ultra-nationalistic political organizations between the end of the 1800's and early 1900 's. Finally, nationalism became the major cause for exploits of terrorism. Although, lately, a clear change has already begun as religion becomes the main motive of terroristic thinking. ${ }^{4}$

Terrorism has been categorised into different forms that "serve to differentiate terrorist organizations according to specific criteria, which are usually related to the field or specialty of whoever is selecting the categories."5 These include: separatist, ethnocentric, nationalistic, revolutionary, political, religious, social, domestic (home-grown), and international or transnational terrorism. ${ }^{6}$ However, terrorism has also been classified into three forms. These are demonstrative terrorism that seeks to be known publicly; destructive terrorism, the kind of terrorism that uses threat, harm and death to mobilize support for their course; and suicide terrorism, the

\footnotetext{
${ }^{3}$ Todd Sandler. "Terrorism and Counterterrorism: An Overview." Oxford Economic Papers, 2014. Accessed $23 \quad$ June 2016. http://oeoxfordjournals.org/content/early/2014/11/05/ oegpu039.full.pdf+html, 1.

4 C. C. Rausch. "Fundamentalism and Terrorism." Journal of Terrorism Research, Volume 6, Issue 2May 2015. http://doi.org/10.15664/jtr.1153, 29.

5 "Categories of Terrorist Groups." Accessed 15 June 2020. research.com/groups/categories.php http://www.terrorism6 "Categories of Terrorist Groups."
}

form of terrorism where the attackers kill themselves with others. ${ }^{7}$

It is unfortunate that "terrorism in the name of religion has become the predominant model for political violence in the modern world." 8 This kind of terrorism is a political violence that is inspired by a total belief that a strange supernatural has authorized terrorist violence for the better exaltation of the belief. It is believed that acts committed because of the belief will be forgiven by the strange force and possibly be rewarded hereafter. ${ }^{9}$ This explains why terrorist attacks are usually linked to one religion or the other. ${ }^{10}$ This has formed part of what is referred to as religious violence - the occurrences where religion is either the purpose or the receiver of violent behaviors. Historically, the world has experienced a great deal of religious violence. ${ }^{11}$ These include; the Judeo-Christian Antiquity as referenced in the Bible, Christian Crusades during the Middle Ages, The Order of Assassins in Persia in 11 th century, A Secret Cult of Murder in India between the 13th and 19th centuries, modern Arab Islamist extremism in the Arab world that passed through several important political phases during the 20th century, mysticism and rebellion in Uganda that had two phases (the Holy Spirit Mobile Force and the Lord's Resistance Army) in 1987, and the Protocols of the Learned Elders of Zion that started in czarist Russia. ${ }^{12}$ Recently, there are ongoing conflicts that involve religious terrorism such as,

conflicts between Jews and Muslims in the Middle East, Hindus and Muslims in India, Catholics and Protestants in Ireland, and Christians and Muslims in the former Yugoslavia, East Timor, Lebanon, Russia, and many countries in Africa [particularly Boko Haram insurgence in] Nigeria; and the killing of physicians and nurses by Christian antiabortion groups.... [Worthy of

\footnotetext{
Ibrahim Suberu. "Martyrs or Terrorists: Suicide Bombing in Islamic Hermeneutics." Ilorin Journal of Religious Studies. Vol. 5 No. 1. 2015, 121.

${ }^{8}$ Gus Martin. Essentials of Terrorism: Concepts and Controversies. Second Edition (Thousands Oaks, Sage Publications, Inc., 2011), 130.

${ }^{9}$ Ibid.

${ }^{10}$ Israela Silberman. "Religious Violence, Terrorism, and Peace: A Meaning-System Analysis." In Raymond F. Paloutzian and Crystal L. Park (eds.). Handbook of the Psychology of Religion and Spirituality (New York: The Guilford Press, 2005), 529.

${ }^{11}$ James Wellman and Kyoko Tokuno. "Is Religious Violence Inevitable?". Journal for the Scientific Study of Religion. 43 (3). Accessed 15 June 2020. https://doi.org/10.1111/i.1468-5906.2004.00234.x, 291.

${ }^{12}$ Martin, Essentials of Terrorism, 131-138.
} 
note are] the 1995 nerve gas attack on the Tokyo subway by Japanese followers of Shoko Asahara in the Aum Shinrikyo sect who were trying to hasten a new millennium, the September 11th, 2001, attacks on the United States in which thousands of civilians were killed by members of the Al-Qaeda organization, and a wave of bombings of civilian buses and public gathering places in Israel by the Islamic Hamas terrorists. ${ }^{13}$

As indicated from examples provided above, terrorism is a global phenomenon. Nevertheless, a report attributed more than 80 per cent of people that lost their lives to terrorist happenings in 2013 happened in only five countries namely, Iraq, Afghanistan, Pakistan, Nigeria and Syria. ${ }^{14}$

Apparently, religion in itself is not the problem of terrorism. This writer agrees with Hill and Kimney that opined that the overzealous adherents of religion are the problem. ${ }^{15}$ All the terrorist acts in the name of religion can be curtailed if every adherent of religion can be tolerant of people of other faiths and be ready to live peacefully with other people regardless of their religious background. One of the most dreaded terrorist groups is the Boko Haram insurgency in the northeastern Nigeria.

\section{BOKO HARAM INSURGENCY IN NIGERIA \\ Boko Haram}

The name Boko Haram, according to Adesoji, is derived from a blending of the Hausa word boko 'book' and the Arabic word haram 'something forbidden, ungodly, sinful' together. Plainly, it means 'book is sinful', but its profound meaning is that Western education is sinful, heretical, or ungodly and should therefore be outlawed. ${ }^{16}$ Although, the real name of the sect is disputed, it is commonly used to refer to a radical Islamist sect in northeastern

13 Silberman. "Religious Violence, Terrorism, and Peace," 529.

14 The Institute for Economics and Peace. Global Terrorism Index Report 2014: Measuring and Understanding the Impact of Terrorism. Accessed June 23, $2016 \quad$ from http://www.visionofhumanity.org/sites/default/files/G lobal\%20Terrorism\%20Index\%20Report\%202014_0 .pdf, 2.

$\frac{.15}{15}$ Jessie Hill and Adam F. Kimney. Sacred Violence: Religion and Terrorism (Cleveland, Ohio: Case Western Reserve University, 2008). Accessed June 23, 2016 from http://scholarlycommons.law.case.edu/cgi/viewconte nt.cgi? article $=1316 \&$ context $=$ jil

16 Abimbola O. Adesoji. "Between Maitatsine and Boko Haram: Islamic Fundamentalism and the Response of the Nigerian State." Africa Today, Vol. 57, No. 4 (Summer 2011), 106.
Nigeria. ${ }^{17}$ In spite of the fact that Azumah agreed that 'Boko Haram' means "Western education is forbidden or sinful" and that the group is "opposed to aspects of Western education because [it believes that Western education] is sinful and religiously forbidden"18. The group had rejected the name for itself as cited in a YouTube video released sometime in 2014. ${ }^{19}$ In support of this, Cook cited an ideological statement issued in 2009 by Sani Umar who was then a temporary leader of the sect:

Boko Haram does not in any way mean "Western Education is a sin" as the infidel media continue to portray us. Boko Haram actually means "Western Civilization" is forbidden. The difference is that while the first gives the impression that we are opposed to formal education coming from the West, that is Europe, which is not true, the second affirms our belief in the supremacy of Islamic culture (not education), for culture is broader, it includes education but not determined by Western Education. ${ }^{20}$

The official name of the sect is Jamaiatu Ahlis Sunna Lidda'awata Wal-Jihad, which means "Association of Sunnis for the Propagation of Islam and Jihad"21 or "People Committed to the Propagation of the Prophet's Teachings and Jihad". ${ }^{22}$ The sect is referred to as "al-Qaeda's African "monsters". ${ }^{23}$ Specifically, the sect "has ties to northwest Africa-based al-Qaeda in the Islamic Maghreb, Somalia's al-Shabab, and al-Qaeda in the Arabian Peninsula."24 Apart from linking itself with

17 B. Maiangwa, et al. "'Baptism by Fire': Boko Haram and the Reign of Terror in Nigeria." Africa Today, Vol. 59, No. 2 (Winter 2012), 45.

18 John Azumah. "'Boko Haram' in Retrospect." Journal of African Christian Thought. Vol. 17, No. 1, June 2014, 57.

${ }^{19}$ Ibid.

20 David Cook. Boko Haram: A Prognosis (The James A. Baker III Institute for Public Policy of Rice University, 2011), 12-13.

${ }^{21}$ Femi Owolade. "Boko Haram: How a Militant Islamist Group Emerged in Nigeria.” Accessed 15 June 2020.

http://www.gatestoneinstitute.org/4232/bokoharam-nigeria

${ }^{22}$ SO Oladimeji. Faith, Stewardship and Security: Christians Collaborating with God to Handle Security Matters (Ibadan, Nigerian Baptist Convention, 2013), 4.

23 Chris Uchenna Agbedo, et al. "Sociopsychological deconstruction of fear of Boko Haram in Nigeria: The Nigerian media perspective." New Media and Mass Communication. Vol.16, 2013, 60.

24 Mohammed Aly Sergie and Toni Johnson. "Nigeria's Boko Haram and Ansaru. Council on 
"Islamic State in Iraq and Syria (ISIS), the leadership of Boko Haram claims today that it wants to be known as the Islamic State West Africa Branch (ISWAB). ${ }^{25}$

\section{Composition of Boko Haram}

Members of Boko Haram, also called Yusuffiya, according to Sergie and Johnson, "consist largely of impoverished northern Islamic students and clerics, as well as professionals, many of whom are unemployed." 26 Eniola added that they "comprise university lecturers, bankers, political elites, drug addicts, unemployed graduates, almajiris and migrants from neighbouring countries like Chad and Niger. Majority of them are the Kanuris from the northeastern region [of Nigeria]." 27 Furthermore, the sect is not a uniform body that has a cohesive purpose because there are many separate groups within the sect that do not agree with strategies that the sect is using, and these factions also compete for attention and followers. ${ }^{28}$ Conversely, this assertion of division in the sect may not be accurate. ${ }^{29}$ Although, this sect is mainly active in the northern Nigeria, its activities are noticeable also in other geographically bordering countries that include Cameroun, Chad and Niger. ${ }^{30}$ It has not less than 1.5 million followers in different Nigerian northern states. ${ }^{31}$ It also has "a hierarchical organization that enables them to effectively plan, command and coordinate operations, gather intelligence, maintain

Foreign Relations." Accessed June 9, 2016. http://www.cfr.org/nigeria/boko-haram/p25739

${ }^{25}$ Virginia Comolli. "Book Haram: Nigeria's Islamist Insurgency." In Christian Century March 2, 2016. Accessed May 4, 2016. http://web.a.ebscohost.com/ehost/pdfviewer/pdfview er?sid=19bcaba2-66e7-4962-a81b-

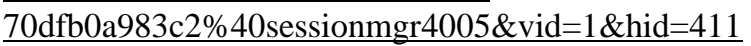
$\frac{2}{2}, 41$.

${ }^{26}$.Mohammed Aly Sergie and Toni Johnson. "Nigeria's Boko Haram and Ansaru. Council on Foreign Relations." Accessed June 9, 2016. http://www.cfr.org/nigeria/boko-haram/p25739

27 Titi Eniola. "Social Impact on Victims of Terrorist Attack: Nigerian Girl Education.” A paper presented at a conference organized by Omoniyi Ogodo Bach at Saarbrucken-Am Staden, Germany on October 8, 2015, 11.

${ }^{28}$ Ibid, 11-12.

${ }^{29}$ Cook. Boko Haram: A Prognosis, 23

${ }^{30}$ Osaretin Idahosa. "Boko Haram and the Nigerian State: A Different Perspective." Glocalism: Journal of Culture, Politics and Innovation. 2015, 3, DOI: 10.12893/gjcpi.2015.3.5, 4.

${ }^{31}$ Philip Oluwole Ukanah. In God's Name: The Story of Nigeria's Religious War and Its Brutal Killings (Ibadan, Divine Press, 2011), 249. security, train and ensure logistics and financial support without being noticed." 32 The sect may not be united in its operations because, in the views of this researcher, it serves the interests of many people and/or organizations in the region. Each person and/or organization wants to use the sect to outwit the other people and/or organizations.

\section{Emergence of Boko Haram}

There are many conflicting reports about the emergence of Boko Haram in Nigeria. While many believe that one Mohammed Yusuf started Boko Haram in 2002, which became prominent in 2009 after his extra-judicial killing, ${ }^{33}$ others argue that "the sect had been in [Nigeria] since the 1970s following the killing of its spiritual leader in Egypt in 1970 by President Gammal Abdel Naseer."34 Ibrahim noted that the sect was a not political miscreant created by some political leaders, but an ideological group who hate western democracy. According to Azumah, Boko Haram's origins can be traced "back to the mid 1990s, to a youth group....in Maiduguri...under the leadership of one Mallam Lawal. Mohammad Yusuf assumed the leadership after Lawal left for studies in Saudi Arabia." 35

Boko Haram has grown into a conflagration that has spread into different parts of northern states of Nigeria and it is "perhaps one of the most wellcoordinated mass-destruction religious violence in Nigeria in recent times." 36 Terwase et al were of the opinion that the inability of the northern part of Nigeria to complete its eight years of ruling Nigeria as a result of the demise of the then President Umaru Yar'Adua and the ambition of Goodluck Jonathan

\footnotetext{
${ }^{32}$ Maiwa'azi Dandaura Samu. "Boko Haram Conflict Research/Anaysis \& Management Preventive Counterterrorism And Sustainable Peacebuilding: Nigeria And Boko Haram Case Study." Center for Justice and Peacebuilding, Eastern Mennonite University, USA. Accessed 15 June 2020. https://www.academia.edu/6777526/BOKO HARA M_CONFLICT_RESEARCH_ANAYSIS and_MA NAGEMENT_PREVENTIVE_COUNTERTERROR ISM_AND_SUSTAINABLE_PEACEBUILDING_N IGERIA AND BOKO HARAM CASE_STUDY, 25.

${ }^{33}$ Oren Dorrell. "Boko Haram: Facts, History, Leaders, and Origins of the Terrorist Group." Accessed $\quad 15 \quad$ June 2020. http://www.huffingtonpost.com/2014/05/09/bokoharam-facts-history_n_5295563.html

34 Omololu Ogunmade. "How Boko Haram Entered Nigeria." Accessed 27 February 2016. http://www.thisdaylive.com/articles/how-bokoharam-entered-nigeria/216981/

$\frac{}{35}$ Azumah. "'Boko Haram' in Retrospect." 55.
${ }^{36}$.Ukanah. In God's Name, 249.
} 
from the southern part who succeeded him empowered the Boko Haram sect to become a veritable tool to fight the government of Jonathan and the people of Nigeria. ${ }^{37}$ This opinion was originally posited by the Late General Andrew Azazi as cited by Liman and corroborated by Sergie and Johnson. ${ }^{38}$ According to Idahosa, it is the belief of many people that,

Boko Haram is leading an armed insurgency against corruption, abusive security forces and economic disparity in northern Nigeria security forces and economic disparity in northern Nigeria and feeding off tension that have existed between Muslim dominated north and Christian dominated south of Nigeria. ${ }^{39}$

Whichever was the correct account of its emergence, Boko Haram has become one of the most feared terrorist sects in the world. Akande argued that, "The Boko Haram insurgence has been described either as a political or religious problem. The fact that the sect itself claims [to] belong to a particular religion, Islam, and often times attacks Christians makes it more religious than political...."40 It is the view of this researcher that it is difficult to specifically say what the sect stands for because of the incoherency in its operation.

As a religious faction, its "combination of a sectarian agenda with violence is distinctive.... [and] its goal [according to the movement's rhetoric] is to create God's kingdom on earth through justice for the poor achieved by the rigid application of Islamic law, or sharia." ${ }^{11}$ As a political movement, it was initially

\footnotetext{
${ }^{37}$ Isaac Terungwa Terwase, et al. "The Psychological Trauma on Boko Haram Victims in Nigeria: Conflict Resolution Perspective." Mediterranean Journal of Social Sciences. Vol 6 No 6 S4 MCSER Publishing, Rome-Italy December 2015, 522.

38 A. Liman. "Boko Haram: Why the Northerners Believe Jonathan is Guilty." Accessed 8 June 2016, from http://leadershing/features/396929/boko-haramnortherners-believe-jonathan-guilty. See also Mohammed Aly Sergie and Toni Johnson. "Nigeria's Boko Haram and Ansaru. Council on Foreign Relations.” Accessed June 9, 2016. http://www.cfr.org/nigeria/boko-haram/p25739.

${ }^{39}$ Idahosa. "Boko Haram and the Nigerian State," 6.

40 Isaac Babarinde Akande. "Church Response to Religious Violence in Borno Baptist Association of Maiduguri Metropolitan Area." A Master of Arts in Theological Studies thesis submitted to the Nigerian Baptist Theological Seminary, Ogbomoso, June 2015, 2.

41 John Campbell. "Boko Haram: origins, challenges and responses." Accessed 15 June 2020.

https://www.ciaonet.org/attachments/27796/uploa $\underline{\mathrm{ds}}$
}

backed by some dissatisfied northern politicians that wanted to use it as influence to perpetuate themselves in power or gain power. It was even alleged that some northern governors made periodic payments to the sect, though it is not clear whether these politicians were in support of the sect or the sect imposed itself on them. ${ }^{42}$

\section{Ideology of Boko Haram}

Boko Haram is seen today as a terrorist group. A Sunni Islamic fundamentalist group that wants to encourage strict system of Sharia law founded. ${ }^{43}$ It is a fanatic Islamic sect whose fundamental beliefs are different from those held by the majority of conventional Muslims in Nigeria. ${ }^{44}$ Superficially, this sect is Islamic, but, operationally, it is criminal and does not have any form of religiousness. It transformed into a Salafist-Jihadist group in 2009. Adherents of the sect believe that their understanding of the Quran is the 'true' Islam. They are of the opinion that this 'true' Islam is all-inclusive and comprises of all facets of the life of a Muslim in readiness for life after death. ${ }^{45}$ They reject Western civilization and its products like education, culture, and modern science. ${ }^{46}$

Among other things, Boko Haram claims to be fighting against:

Western ways of life which include: constitutional provision as it relates to, for instance the rights and privileges of women, the idea of homosexualism [sic], lesbianism, sanctions in cases of terrible crimes like drug trafficking, rape of infants, multi-party democracy in an overwhelmingly Islamic country like Nigeria, blue films, prostitution, drinking beer and alcohol and many others that are opposed to Islamic civilization. ${ }^{47}$

\section{Some Terrorist Activities of Boko Haram}

Since the demise of its first known leader, Mohammed Yusuf, the sect has killed over 4000 people. ${ }^{48}$ It has bombed notable places like Nigeria's

\footnotetext{
42 "Anatomy of African Terrorism: Boko Haram: Nigeria's Homegrown Terror Network". World Policy Journal, Vol. 29, No. 4 (Winter 2012 / 2013), 16.

${ }^{43}$ Idahosa. "Boko Haram and the Nigerian State,"12.

44 Adesoji. "Between Maitatsine and Boko Haram," 108.

${ }^{45}$ Idahosa. "Boko Haram and the Nigerian State," 12.

46 Adesoji. "Between Maitatsine and Boko Haram," 106, 108.

${ }^{47}$ Cook. Boko Haram: A Prognosis, 14.

48 Oren Dorrell. "Boko Haram: Facts, History, Leaders, and Origins of the Terrorist Group." Accessed $15 \quad$ June 2020. http://www.huffingtonpost.com/2014/05/09/bokoharam-facts-history n 5295563.html.
} 
police headquarters on June 7, 2011, the building of the United Nations in Abuja, Nigeria on August 16, 2011, and many churches and villages mostly in the northeastern part of Nigeria. ${ }^{49}$ According to Agbedo, et al, "since 2011, Boko Haram had launched its deadliest attacks with such meteoric velocity and clinical efficiency that not only overwhelmed the nation's security agencies but numbed their response instincts and reduced their alert level to near zero." 50 Sewakpo highlighted some of the activities and attacks of Boko Haram from June 2009 to January $2012 .{ }^{51}$ The kidnap of over 200 schoolgirls in 2014 made the sect gain wider notoriety in the western world. ${ }^{52}$ Bombing of villages and sporadic killings of villagers by Boko Haram have displaced many people in the northern part of Nigeria while most of them are camped in internally displaced persons' centers located in various places in the north.

\footnotetext{
${ }^{49}$ Femi Owolade. "Boko Haram: How a Militant Islamist Group Emerged in Nigeria." Accessed 15 June 2020.
}

http://www.gatestoneinstitute.org/4232/bokoharam-nigeria.

Agbedo, et al. "Socio-psychological deconstruction," 68.

${ }^{51}$ H. M. Sewakpo. "The Relationship Between the Pre-Conversion Character of Paul in Acts 8-9 and the Nigerian Boko Haram Insurgence: Implications for Peaceful Coexistence in Nigeria." In Ayantayo, Jacob K. and Samuel Adetunji Fatokun (eds.) (2015). Religion and Security Issues: Proceedings of 2013 Biennial International Religious Studies Conference. Religious Studies Series, Volume 5. Ibadan, Department of Religious Studies, University of Ibadan, Ibadan, 216-217.

52 John Campbell. "Boko Haram: origins, challenges and responses." Accessed 15 June 2020.

https://www.ciaonet.org/attachments/27796/uploa ds. 
Boko Haram-attributed Attacks in Nigeria Since July 2009

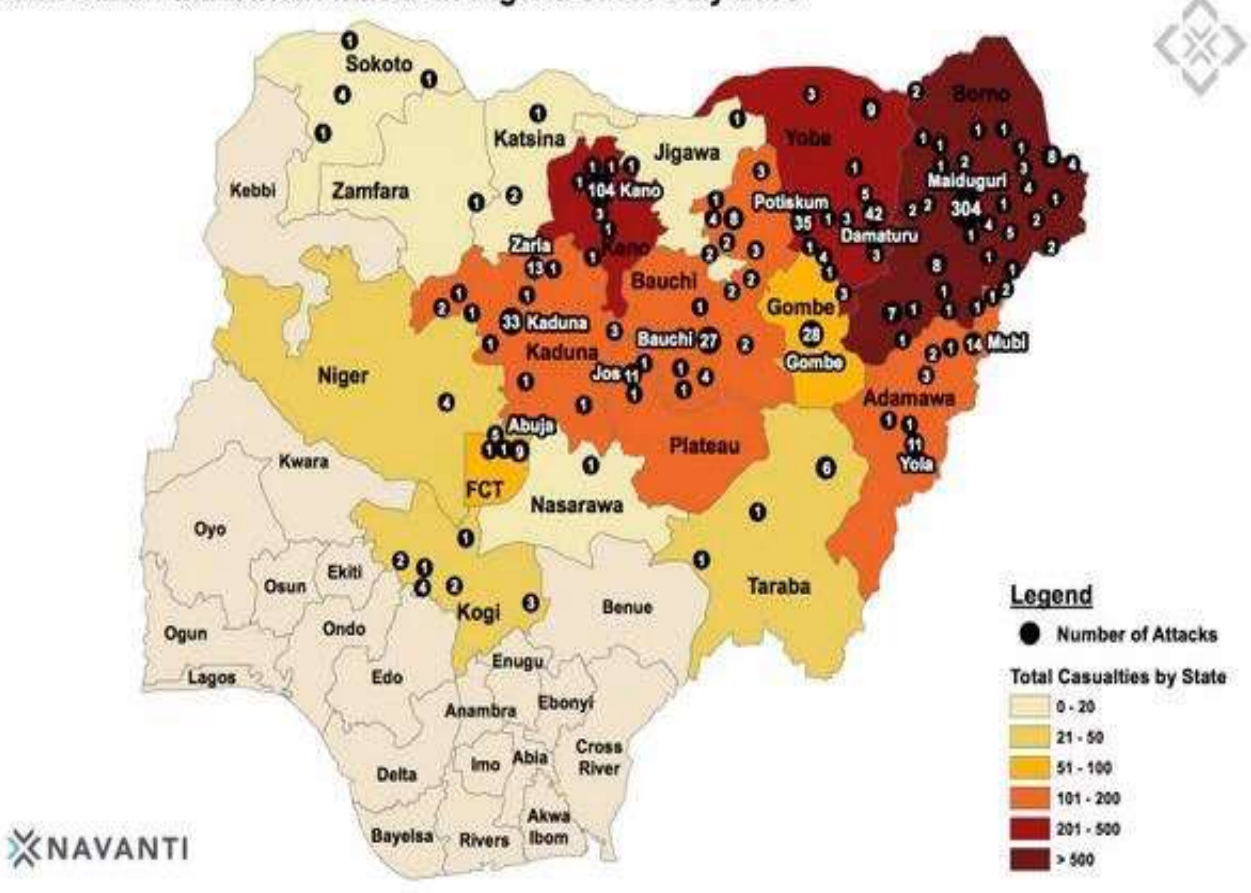

\section{Figure 1: Map of Nigeria Showing Boko Haram Attacks Since July 200953}

In Ukanah's words, one of the effects of religious conflicts in the northern part of Nigeria which Boko Haram has become a major one "is mass movement of people from the affected areas to other areas, states or in the case of the non-indigenes [to] their home-towns." 54 A report confirms that, "over a million Christians in Northern Nigeria have become internally displaced or have settled in other areas of Nigeria in search for safety and security." 55 Many of these people have come back to Ogbomoso town and vicinity. In fact, “the shock of 'Boko Haram' attacks and fear of the group has paralysed parts of northeastern Nigeria, from ordinary citizens to politicians, the security forces, local journalists, religious leaders and scholars. Many people in northern Nigeria are fearful even to mention the name "Boko Haram." 56 Since members of Boko Haram sect claim to be

53 "The crisis in Nigeria, in 11 maps and charts Vox." Accessed 15 June 2020. http://www.vox.com/2014/5/13/5710484/bokoharam-maps-charts-nigeria.

${ }^{54}$ Ukanah. In God's Name, 351.

55 Arne Mulders. Summary of the Research Report 'Crushed But Not Defeated, the Impact of Persistent Violence on the Church in Northern Nigeria'. Open Doors International, February 2016, 4.

${ }^{56}$ Azumah. "'Boko Haram' in Retrospect," 50. propagating Jihad, it is necessary to know more about this concept.

\section{JIHAD}

A common definition of the word jihad is "to struggle or strive [in the way or sake of Allah]" or, as erroneously defined by many people, "a holy war undertaken by Muslims against non-believers". ${ }^{57}$ Boer argued that "the meaning of jihad varies greatly among Muslims; it can be violent or peaceful, communal or personal, political or spiritual." 58 Malik opined that the primary meaning of Jihad "is investing effort (in the sense of energy) in order to achieve a particular aim, or to endure an effort (in the sense of a difficulty) caused by carrying out an action or putting a message into practice." ${ }^{59}$

57 “The True Meaning of Jihad." Accessed 10 June 2016.

http://www.justislam.co.uk/product.php?products_id $\frac{=2}{58}$

${ }^{8}$ Jan H. Boer. Christians and Muslims: Parameters for Living Together. Studies in Christian-Muslim Relations. Volume 8, Part 2. Belleville, Essence Publishing, 2009), 323.

59 Ibrahim Malik. "Jihad - Its Development and Relevance." The Palestine-Israel Journal. Vol.1 No.2 1994 / Religion and Politics. Accessed 15 June 2020. http://www.pij.org/details.php?id=741 
Having corrected the erroneous belief that jihad is an armed conflict or fanatical holy war, it is worth noting that there are two kinds of jihad - the greater jihad and the lesser jihad. The former is the internal struggle that each person has in order to do what is right and good, while the later has to do with the outward (which includes military) defense of Islam when the Islamic community is under attack. ${ }^{60}$ It has to be noted also that everything boils down to interpretation and application of the Quran by Islamic clerics. The reason is that there are parts of the Quran that give room for such fierce interpretations.

Nevertheless, various terrorist groups (Boko Haram inclusive) have portrayed jihad as a 'holy war' they are fighting in the cause of Allah. In contrast, many Muslim scholars have dissociated Islam from such activities. Quoting severally from Hadith"1, Suberu asserted, "Islam has made it forbidden for a Muslim to kill another Muslim or to kill another person unlawfully." 62 In fact, Ahmad emphatically declared: "as far as Islam is concerned, it categorically rejects and condemns every form of terrorism. It does not provide any cover or justification for any act of violence, be it committed by an individual, a group or a government" 63 Therefore, it can be concluded that all terrorist groups claiming to be fighting a holy war of jihad to propagate Islam are doing so erroneously or with other ulterior motives. Such terrorist actions have caused many people to have one kind of trauma or the other.

\section{TRAUMA}

Simply, trauma is a deeply distressing or disturbing experience. Among other things, what can result to trauma include: physical and sexual abuse, neglect, bullying, community-based violence, disaster, terrorism, war and the likes. ${ }^{64}$ While other injuries can be less evident, but have equally disheartening consequences, seeing dreadful violence and witnessing the bloody outcome can lead to emotional trauma and impact damagingly on psychosocial welfare. ${ }^{65}$ Post-traumatic stress disorder (PTSD) has been identified as the most frequently reported consequence of war exposure. ${ }^{66}$

\footnotetext{
${ }^{60}$ Martin, Essentials of Terrorism, 142.

${ }^{61}$ Hadith is a collection of traditions containing sayings of the Prophet Muhammad.

${ }^{62}$ Suberu. "Martyrs or Terrorists," 133.

${ }^{63}$ Hazrat Mirza Tahir Ahmad. Murder in the Name of Allah (Amritsar: Printwell, 1990), 116.

64 "Trauma and Violence." Accessed 15 June 2020. http://www.samhsa.gov/trauma-violence/types

${ }^{65}$ The Institute for Economics and Peace, 71.

66 Branis Knezevic and Seth Olson. "Counseling People Displaced by War: Experiences of Refugees
}

There are three categories of people that are affected by trauma as a result of terrorism. These categories of people are:

- $\quad$ Survivors of past traumatic events (e.g., refugees of wars, terrorism or torture, and survivors of domestic violence, child abuse or street crime). These individuals may have a heightened sense of vulnerability.

- $\quad$ People who personally witnessed or were victims of the terrorist attack.

- People who experience traumatization from learning of relatives, friends and acquaintances who were subject to the violence, or from exposure to repeated media accounts of the trauma. ${ }^{67}$

While there are many instances of terrorist attacks that have led to trauma both to people that are directly affected and people who are indirectly affected. ${ }^{68}$ Boko Haram terrorism has affected many people, and this has led to psychological trauma. ${ }^{69} \mathrm{~A}$ good example of the victims of the Boko Haram terrorism that were emotionally affected were the parents of the Chibok girls who were abducted from school by boko haram terrorists. ${ }^{70}$ Unfortunately, there is lack of proper mental health support from the government and other organizations for the affected people in dealing with psychological and physical trauma associated with these Boko Haram insurgents. $^{71}$ In the view of this researcher, the government is just playing a lip service to the transformation of the people that are affected by the insurgency, and this has turned many of the affected people to internally displaced people.

\section{INTERNALLY DISPLACED PERSONS}

In spite of many debates about who internally displaced persons (IDPs) are, they could be referred to as;

from the Former Yugoslavia." Professional Counselor. Vol. 4, No. 4, 2014.

${ }^{67}$ American Psychological Association. "Managing traumatic stress: Coping with terrorsm." Accessed 23 June 2016. http://www.apa.org/helpcenter/terrorism.aspx

${ }^{68}$ See the activities of the Boko Haram insurgency above.

${ }^{69}$.Terwase, et al. "The Psychological Trauma on Boko Haram Victims in Nigeria," 522-524.

70 "Boko Haram insurgents abducted these girls on the 14th April 2014 in their secondary school in Chibok, a town in northeastern part of Nigeria."

71 Jocelynn Ramiah. "The Boko Haram Insurgency and The Hardships Faced by Its Victims." Ifriqiya Africa Research and Analysis. Volume 1, Number 8 October 20, 2015, 4. 
persons or group of persons who have been forced to leave their homes or places of habitual residence as a result of, or in order to avoid, in particular, the effects of armed conflict, situations of generalized violence, violations of human rights or natural or human-made disasters, and who have not crossed an internationally recognized state border. ${ }^{72}$

By the end of 2014, there was a record of 38 million people around the world that have been forced to abandon their homes and become displaced within the borders of their own countries. ${ }^{73}$ Out of these people 2.4 million live in Nigeria. ${ }^{74}$ As of 31 December 2015, there was an estimate by the Internal Displacement Monitoring Centre "that there are almost 2,152,000 internally displaced people (IDPs) in Nigeria."75 These people are displaced mostly by conflicts among various ethnic groups or between governments and minorities of various race, language, culture, or religion. ${ }^{76}$ Cordell and Wolff identified and explained these four causes or theories "on the different conceptual tools scholars employ in their efforts to explain": insecurity, 'greed', socialpsychological motivations and the international dimension of ethnic conflict. ${ }^{77}$ In the case under study, the root cause of the displacement may seem to be mainly religious ${ }^{78}$, but there are also political, economic, cultural, historical and other strategic

72 Janie Hampton (ed.). Internally Displaced People: A Global Survey (London, Earthscan Publications Ltd, 1998), xvi.

73 "Global Overview 2015: People internally displaced by conflict and violence." Accessed 27 February 2016, from http://www.internaldisplacement.org/assets/library/Media/201505-

Global-Overview-2015/20150506-global-

overview-2015-en.pdf, 7.

${ }^{74}$ Conflict Barometer 2015, 13.

75 "IDMC Nigeria IDP Figures Analysis." Accessed 15 July 2016. http://www.internaldisplacement.org/sub-saharan-africa/nigeria/figuresanalysis

${ }^{76}$ Roberta Cohen and Francis M. Deng (eds.). The Forsaken People: Case Studies of the Internally Displaced (Washington DC, The Brookings Institution, 1998), 3.

${ }^{77}$ Karl Cordell and Stefan Wolff. Ethnic Conflict: Causes - Consequences - Responses (Cambridge, Polity Press, 2010), 26-43.

${ }^{78}$ In 2011, Israel Adelani Akanji has submitted $\mathrm{PhD}$ dissertation to the University of Edinburgh titled TOWARDS A THEOLOGY OF CONFLICT TRANSFORMATION: A STUDY OF RELIGIOUS CONFLICT IN CONTEMPORARY NIGERIAN SOCIETY. motivations to the cause. ${ }^{79}$ In fact, an international delegation of Muslims and Christians that visited Nigeria between 22nd and 26th May 2012 subdivided the causes of conflicts in Nigeria into; "religious, political, economic, social/ethnic and legal". ${ }^{80}$ Furthermore, additional view of Oduwole and Fadeyi that "Nigeria regularly experiences displacement as a consequence of natural disasters such as flooding or soil erosion" 81 cannot be overlooked here. Many people have been displaced by these natural disasters almost on yearly basis.

Many documents have been produced as guidelines for the protection of internally displaced persons. One of such documents is the Handbook for the Protection of Internally Displaced Persons. ${ }^{82}$ The aims of that document are to:

- ensure staff members are familiar with the core concepts, principles and international legal standards that form the framework for protection work;

- assist staff in operationalizing these concepts, principles and legal standards and in carrying out their protection responsibilities;

- improve understanding of the particular protection risks faced by internally displaced women, men, boys and girls of various backgrounds;

- $\quad$ provide guidance on how to prevent and respond to the protection risks faced by IDPs through a range of different activities; enhance staff skills for carrying out protection work; and

- promote a consistent and wellcoordinated protection response in different operations. ${ }^{83}$

"The Guiding Principles Of Internal Displacement" was also published. ${ }^{84}$ These principles

\begin{tabular}{lcccr}
\hline 79 & Samu. & \multicolumn{1}{c}{ "BOKO } & HARAM & CONFLICT \\
RESEARCH," 9. & & & \\
80 & "REPORT & ON & THE & INTER-RELIGIOUS \\
TENSIONS & AND & CRISIS & IN & NIGERIA." \\
Accessed & 15 & & June & 2020.
\end{tabular}

https://www.oikoumene.org/en/folder/documentspdf/Report_of_Nigeria delegation.pdf, 9.

${ }^{81}$ Tajudeen A. Oduwole and Adebayo O. Fadeyi. "Issues of Refugees and Displaced Persons in Nigeria." Journal of Sociological Research. ISSN 1948-5468 2013, Vol. 4, No. 1, 2.

${ }^{82}$ UN High Commissioner for Refugees. Handbook for the Protection of Internally Displaced Persons. Accessed $15 \quad$ June 2020. http://www.unhcr.org/4c2355229.pdf.

3 Handbook for the Protection of Internally Displaced Persons, 2. 
as highlighted by Oduwole and Fadeyi are: the rights of IDPs and the responsibilities of national authorities; the issue of protection from displacement and the right not to be arbitrarily displaced; the full range of civil, political, economic, social and cultural rights that all persons (including the displaced people) should enjoy, and that special attention should be given to the prevention of contagious and infectious diseases; the issue of humanitarian assistance and services from international organization; and the importance of providing the displaced people with long-term options of voluntary return in safety and dignity to their original place of abode or resettlement in another part of the country, equal access to public services, and assistance to recover the property and possessions the displaced people lost upon displacement or assistance to get compensation or other forms of just reparation. ${ }^{85}$

${ }^{84}$ F.M. Deng. "Internally Displaced Persons: An interim report of the UN Secretary General on protection and Assistance, New YorK: Un Dept. for Humanitarian Affairs, Washington, D.C., U.S.A; Francis M. Deng (1999). Guiding Principles on Internal Displacement." The International Migration Review, Vol. 33, No. 2 (Summer, 1999); Roberta Cohen. "The Guiding Principles on Internal Displacement: An Innovation in International Standard Setting." Global Governance, Vol. 10, No. 4 (Oct.-Dec. 2004); Walter Kälin. "Guiding Principles on Internal Displacement: The Way Ahead." Proceedings of the Annual Meeting (American Society of International Law), Vol. 102 (APRIL 9-12, 2008).

${ }^{85}$ Oduwole and Fadeyi. "Issues of Refugees," 7-10. . 


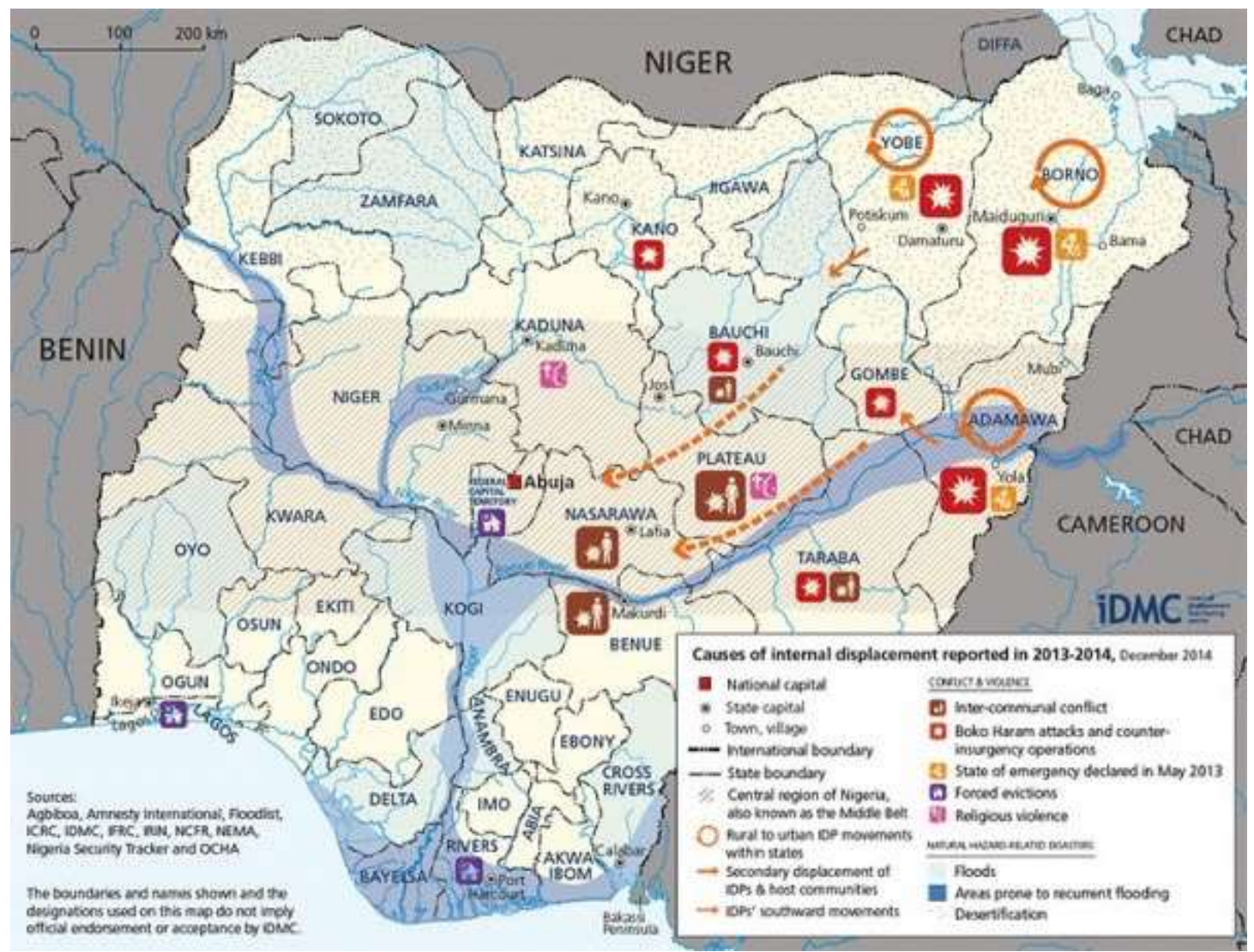

Figure 2: Map of Nigeria showing the Movement of Internally Displaced Persons ${ }^{86}$

\section{CHRISTIAN THEOLOGICAL BASIS FOR HUMANITARIANISM}

To be humanitarian is to have concern for or help to improve the welfare and happiness of fellow human beings. The Holy Bible states, "God created man in His own image" (Genesis 1:27). ${ }^{87}$ With this assertion, every human being is to be treated with dignity irrespective of the situation he/she finds him/herself. This is the foundation of every other teaching of the Bible about how to relate with or treat other human beings. As a matter of fact, the Bible affirms that whatever a man does to his fellow human being (especially the less-privileged), he does it to his Creator. The writer of the book of Proverbs stated: "He who oppresses the poor reproaches his Maker"

86 "IDMC: Nigeria Internal Displacement as of December 2014." Accessed 23 June 2016. http://www.internal-displacement.org/sub-saharanafrica/nigeria/2014/nigeria-internal-displacement-asof-december-2014

${ }^{87}$ Bible verses used in this dissertation (unless marked otherwise) are taken from the New King James Version ${ }^{\circledR}$. Copyright (C) 1982 by Thomas Nelson. Used by permission. All rights reserved. and "He who has pity on the poor lends to the Lord" $(14: 31 ; 19: 17)$. Jesus Christ reiterated this in His Parable of the Sheep and the Goats in Matthew 25:31-46: "assuredly, I say to you, inasmuch as you did it to one of the least of these My brethren, you did it to Me.... Assuredly, I say to you, inasmuch as you did not do it to one of the least of these, you did not do it to Me" (verses 40, 45).

The exodus of the people of Israel from Egypt and later exile in foreign lands are good examples of migrated displaced persons (see Exodus $13 \mathrm{ff}$ and 2 Kings 24:10-16). The people were cared for on their journey to the land of Canaan, and countries that refused to care for them were punished (see 1 Samuel 15:2). Because of these experiences, God instructed the people of Israel not to discriminate against the less privileged and strangers (including those who are temporarily displaced, internally displaced, or forced out of their homeland to become refugees in other countries), rather the people of Israel should take care of, and respond with love and justice to the plight of displaced persons. ${ }^{88}$ The writers of New Testament

\footnotetext{
${ }^{88}$ Exodus 22:21; Leviticus 19:10, 34;

25:35;Deuteronomy 10:19; 27:19.
} 
also re-echoed this. ${ }^{89}$ Taking care of people in needs is even considered the pure religion! 90

This statement from a Roman Catholic publication summarizes the Christian theological basis for humanitarianism:

...the Church's commitment to migrants and refugees can be attributed to the love and compassion of Jesus.... By responding to the divine commandment and attending to the spiritual and pastoral needs of them, the Church not only promotes the human dignity of each human person [made in the image of God], but also proclaims the Gospel of love and peace in situations of forced migration. ${ }^{91}$

Helping other people is, therefore, considered by Christians as a very vital aspect of their religious obligations.

\section{BAPTIST POLICY/THEOLOGICAL STAND ON HUMANITARIANISM}

Against the backdrop of the efforts of the churches of the Nigerian Baptist Convention in transforming the lives of the migrated displaced Boko Haram victims in Ogbomoso land, they will be singled out here. The Nigerian Baptists in particular and other Baptists throughout the world believe wholly in the Holy Bible. ${ }^{22}$ Therefore, the Baptists generally believe everything the Holy Bible teaches about humanitarianism. There are some specific efforts of the Baptists in general and the Nigerian Baptists in particular that express their policy and theological stand on humanitarianism, especially in reaction to the issue of internally displaced persons.

\footnotetext{
${ }^{89}$ Romans 12:13; 1 Thessalonians 4:12; Hebrews 13:1-3.

${ }^{90}$ Micah 6:8 and James 1:27.

91 "WELCOMING CHRIST IN REFUGEES AND

FORCIBLY DISPLACED PERSONS: Pastoral

Guidelines." Accessed 15 June 2020.

http://www.vatican.va/roman_curia/pontifical_counci ls/corunum/corunum en/pubblicazioni_en/Rifugiati2013-INGL.pdf, 3.

92 "Statements of Faith of the Nigerian Baptist

Convention.” Accessed 15 June 2020.
}

https://www.nigerianbaptist.org/about-us/statementsof-faith/; "What Does a Baptist Believe?" Accessed February 27, 2016, from

http://www.baptistbasics.org/baptists/b003.php;

"Southern Baptist Convention Basic Beliefs."

Accessed 15 June 2020.

http://www.sbc.net/aboutus/basicbeliefs.asp; "What

Makes a Baptist a Baptist: Beliefs, polity, ministries, practices, organizations, and heritage of Baptists."

Accessed 15 June 2020.

https://www.baptistdistinctives.org/resources/articles/ what-makes-a-baptist-a-baptist/
In the annual gathering held between 4th and 9th July 2016 in Vancouver, Canada, the Baptist World Alliance (BWA) ${ }^{93}$ encouraged "Christian believers to personally engage with all refugees and displaced persons, generously showing God's love and care as we demonstrate the sufficiency of God made known through Jesus Christ." 94 The body has earlier adopted some resolutions in one of its councils in $2013 .{ }^{95}$ One of the resolutions is about internally displaced persons. Having remembered, recalled and affirmed some of the theological basis for caring for displaced people as enumerated above, the alliance, enourages Baptists to uphold the human rights of all people at all times, including the rights of displaced persons, asylum seekers and refugees; it calls upon governments to uphold universal human rights and develop just and compassionate policies with provisions for:

- access to the protections afforded to displaced persons in the international law including non-discrimination with respect to religious and ethnic identity;

- access to adequate psychological, social, and medical care;

- ensuring that displaced persons whose claim for refugee status has been denied are treated fairly while awaiting repatriation;

Urges governments to use peaceful means to address human rights violations in countries of origin and to pursue policies to strengthen regional cooperation and expand protection of displaced persons;

Encourages political leaders to demonstrate ethical and non-partisan leadership in policy debates on immigration and the global movement of displaced persons; and

\footnotetext{
${ }^{93}$ The Baptist World Alliance is a global movement of Baptists sharing a common confession of faith in Jesus Christ bonded together by God's love to support, encourage and strengthen one another while proclaiming and living the Gospel of Jesus Christ in the power of the Holy Spirit before a lost and hurting world. (See "Baptist World Alliance - Affirmations." Accessed 15 June 2020. http://bwanet.org/aboutus2/affirmations.) The Nigerian Baptist Convention is affiliated to the global body.

94 "Baptist World Alliance - News Releases."

Accessed 9 July 2016, from http://bwanet.org/news/news-releases

95 "Baptist World Alliance - 2013 Resolutions."

Accessed 27 February 2016, from

https://www.bwanet.org/resources/recentresolutions.
} 
Encourages Baptists to act as advocates for displaced persons and to develop plans to respond with compassion and hospitality to the needs of displaced persons. ${ }^{96}$

As good as this resolution is, there is no qualitative means to know how member bodies of this global alliance are implementing the resolution. Sequel to the prevalent issue of the internally displaced persons in Nigeria, the Nigerian Baptist Convention also as part of the resolutions adopted in its annual session held in Ilorin, Nigeria between 16th and 21st April 2016 called on the government of Nigeria to take some palpable measures to alleviate the plights of the internally displaced persons. ${ }^{97}$ Unfortunately, such calls have not yielded good result as the government does not see the need to come to the aid of these displaced people. When palliative measures were taken, they usually have political undertone.

\section{RESPONSE OF RELIGIOUS BODIES TO INTERNALLY DISPLACED PERSONS' CRISIS AROUND THE WORLD}

In spite of the fact that religion has sometimes been seen as "a source of great conflict and is popularly presented as a negative social force," 98 and "caution is required at the very beginning of any discussion of religion as a resource... for the resolution of conflicts," 99 many religious bodies have made, and are still making, attempts to respond to conflicts and people affected by conflicts throughout the world and in Nigeria in particular. In a research carried out in a southeastern state of Nigeria, many internally displaced persons that were interviewed "affirmed that most of the services were received from the religious groups and good samaritans, not from the government." 100 There is a situation update in the northeastern part of Nigeria that "the displaced

\footnotetext{
96،"Baptist World Alliance - 2013 Resolutions."

97 "Report of the Resolution Committee of the

Nigerian Baptist Convention-In-Session held at Convention Ground, Ganmo, Ilorin, Kwara State, Nigeria between April 16-21, 2016" (Unpublished)

98 John D. Brewer. Peace Process: A Sociological Approach (Cambridge, Polity Press, 2010), 56.

${ }^{99}$ Raymond G. Helmick, S.J. "Does Religion Fuel or Heal in Conflicts?” In Helmick, S.J., Raymond G. and Rodney L. Petersen (eds.). Forgiveness and Reconciliation: Religion, Public Policy \& Conflict Transformation (Radnor, Templeton Foundation Press, 2001), 81.

${ }^{100}$ EE Enwereji. "Assessing interventions available to internally displaced persons in Abia state, Nigeria.” DOI: 10.4176/ 080725, 25.
}

people live in churches, mosques"101 Unfortunately, many of such responses, especially from churches in the southwestern part of Nigeria, are not documented for review.

The World Council of Churches that is considered to be "the broadest and most inclusive among the many organized expressions of the modern ecumenical movement"102 in the world is in the forefront in the efforts to transform the lives of displaced persons from conflict-affected areas. During the council's Executive Committee meeting held between 7 th and 12th February 2014, it issued a statement on rights of internally displaced persons. ${ }^{103}$ This comprehensive statement has become a blueprint for many churches as they respond to transforming the lives of displaced people from conflict-affected areas. Later that same year, between 20th and 26th November, the council's Executive Committee issued another statement urging the protection of refugees and displaced persons from the Middle East. ${ }^{104}$ Earlier, between 22nd and 26th May 2012, the World Council of Churches with The Royal Aal al-Bayt Institute for Islamic Thought ${ }^{105}$ jointly sponsored an international delegation of Muslims and Christians to visit Nigeria. The visit was "in reaction to the numerous incidents of fierce intercommunal strife which has affected the lives of Nigerians

101 "2015 Humanitarian Needs Overview. Nigeria."

Accessed 15 June 2020.

http://reliefweb.int/sites/reliefweb.int/files/resources/ HNO\%20Nigeria\%20-

\%20Final\%20version\%2015March\%202015.pdf, 11.

See also page 13 .

102 "What is the World Council of Churches?"

Accessed 15 June 2020.

https://www.oikoumene.org/en/about-us

103 "Statement on rights of internally displaced persons - World Council of Churches." Accessed 15 June 2020.

https://www.oikoumene.org/en/resources/documents/ executive-committee/geneva-february2014/statement-on-rights-of-internally-displacedpersons

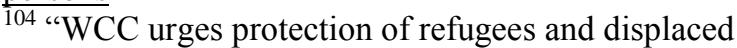
people from the Middle East - World Council of Churches." Accessed 15 June 2020.

https://www.oikoumene.org/en/presscentre/news/wcc-urges-protection-of-refugees-anddisplaced-people-from-the-middle-east ${ }^{105}$ The Royal Aal al-Bayt Institute for Islamic Thought is an international Islamic nongovernmental, independent institute headquartered in Amman, the capital of the Hashemite Kingdom of Jordan. (See "The Royal Aal al-Bayt Institute for Islamic Thought." Accessed 15 June 2020. http://aalalbayt.org/en/index.html.) 
between 2000 and2012."106 The two bodies later promised to contribute their quotas to peacebuilding in Nigeria. ${ }^{107}$

The Roman Catholic Church, another big Christian body has also responded in many ways to transforming the lives of displaced persons from conflict-affected areas. One of the ways the church has done this is by releasing a document ${ }^{108}$ on refugees and forcibly displaced persons in 2013. The purpose of the document is "to direct and raise renewed awareness to the various forms of forced migration and the challenges as a community in welcoming them, showing compassion, treating them fairly which are just a few simple steps to take, yet offer them hope for the future."109 This document reiterates the beliefs of the Roman Catholic Church in the theology of charity; the concepts of refugees and internally displaced persons; the rights of refugees and internally displaced persons, and the responsibilities of governments, non-governmental organizations and international bodies to these people; and specific pastoral care to refugees and internally displaced persons. Indeed, this document is timely and germane, not only to Roman Catholics but every Christian and other persons who care about the transformation of the lives of displaced persons from conflict-affected areas. A practical example of church's response to transforming the lives of displaced persons from conflict-affected areas is what the church in Colombia is doing. ${ }^{110}$ According to the report, the Episcopal Church "provides temporary housing, food, medicine and clothing with financial [assistance]" for the displaced persons.

There are many practical ways in which churches in Nigeria have responded to transforming the lives of displaced persons from conflict-affected areas. Gish In 2014, members of Ekklesiyar Yan'uwa a Nigeria (EYN), ${ }^{111}$ in Jos, north central Nigeria

\footnotetext{
106 "REPORT ON THE INTER-RELIGIOUS TENSIONS AND CRISIS IN NIGERIA.” Accessed 15 June 2020.

https://www.oikoumene.org/en/folder/documentspdf/Report of Nigeria delegation.pdf, 2 . 107 "REPORT ON THE INTER-RELIGIOUS TENSIONS AND CRISIS IN NIGERIA", 12-13. 108 "WELCOMING CHRIST IN REFUGEES AND FORCIBLY DISPLACED PERSONS." The document is actually an update to an earlier publication of the 1992 titled "Refugees, A Challenge to Solidarity".

${ }^{109}$ Ibid.,5.

${ }^{110}$ Lynette Wilson. "Colombia Church stands with internally displaced people Episcopal Church." Accessed 15 June 2020.

http://www.episcopalchurch.org/library/article/colom bia-church-stands-internally-displaced-people

${ }^{111}$ That is, Church of the Brethren in Nigeria.
}

helped the displaced Boko Haram victims with rented accommodations and food provisions. ${ }^{112}$ Apart from this, EYN, which is a faith-based organization is building new houses in safer areas of northeastern Nigeria for families of displaced persons that are not able to go back to their home communities. Such buildings are sited in Masaka, Gurku, Yola, Jalingo, Chinka in northeastern Nigeria and two other locations in Jos. The church provided roofing materials, household supplies, seeds for planting and fertilizer for displaced people that can return to their homes. The church also supports the displaced people with finance to start up micro businesses, skills acquisition and provision of equipment and tools to start up their businesses. ${ }^{113}$

Furthermore, in collaboration with the Nigeria Crisis Response and the Mennonite Central Committee (MCC), the Ekklesiyar Yan'uwa a Nigeria held trauma awareness workshops. They also trained additional facilitators to reach more people in their own places. In terms of education of the displaced children, the church runs temporary schools where trained teachers that are also displaced are employed temporarily to teach the children. EYN also supported displaced orphans in their education, and it provides school fees for children in other places where it does not have its self-managed schools. The church also provides medical care in temporary IDP camps, churches, at new relocation centres, and at existing clinics. ${ }^{114}$ Undoubtedly, this church has contributed a lot to transforming the lives of displaced people from conflict-affected areas in the northeastern part of Nigeria.

Oduah gave another report of how nearly 2,700 internally displaced persons left governmentoperated IDP camps in Adamawa State in the northeastern Nigeria because of food shortages and overcrowding and came to St. Theresa Roman Catholic Church, Yola, the state capital, where there was shelter for both Christians and Muslims. ${ }^{115}$

Christian Aid is a faith-based organization that is providing vital, practical and efficient assistance

\footnotetext{
${ }^{112}$ Peggy Gish. "NIGERIA: Church of the Brethren family cares for fifty-two people displaced by Boko Haram." Accessed 15 June 2020.

http://www.cpt.org/cptnet/2015/05/27/nigeriachurch-brethren-family-cares-fifty-two-peopledisplaced-boko-haram

113 "Responding to the Crisis." Accessed 10 June 2016, from http://www.brethren.org/nigeriacrisis/response.html 114 "Responding to the Crisis."

${ }^{115}$ Chika Oduah. "A holy burden: Nigerian religious groups aid Boko Haram victims." Accessed 15 June 2020.

http://america.aljazeera.com/articles/2015/2/26/carryi ng-a-holy-burden-in-nigeria.html
} 
where demand is huge, and confronting the consequences of poverty as well as its foundational causes. ${ }^{116}$ Its first humanitarian project in response to the conflict in Benue State in north central part of Nigeria, where it worked with its partners, the Jireh Doo Foundation (JDF) and Anglican Diocesan Development Service (ADDS) Makurdi in responding to the plights of internally displaced persons in the area, is documented in a report it published in July 2015. ${ }^{117}$

The Nigerian Baptist Convention is also responding to transforming the lives of displaced persons from conflict-affected areas. The Convention has a department that coordinates its social ministry in general. ${ }^{118}$ This department is a replica of an international agency of the Baptist World Alliance (called BWAid) that has been providing relief worldwide "for all who are in need, regardless of race or religion." 119 As part of the alliance's objectives to equip churches for humanitarian services, the alliance produced a directory that contains "a listing of human rights organizations in various countries and territories, regional human rights organizations and international human rights bodies." 120

\section{CONCLUSION}

Boko Haram insurgency is still ongoing mostly in the northeastern part of Nigeria in spite of the purported claims by the Nigerian government that the insurgency has been decimated. ${ }^{121}$ The incessant

\footnotetext{
${ }^{116}$ Christian Aid Nigeria. "Reaching out: Emergency Humanitarian Relief Assistance project, Benue, Nigeria." Accessed 10 June 2016.

http://www.christianaid.org.uk/Images/Reaching-outhumanitarian-report-July-2015.pdf, 2.

${ }_{117}$ Christian Aid Nigeria. "Reaching out".

118 "Nigerian Baptist Convention Social Ministry" https://www.nigerianbaptist.org/departments/socialministries-department/

119 "Baptist World Aid." Accessed June 10, 2016. https://www.bwanet.org/programs/baptist-world-aid ${ }^{120}$ Division on Freedom and Justice of the Baptist World Alliance. Global Human Rights Contacts. Accessed 15 June 2020.

http://www.bwanet.org/images/pdf/hrorganizations.pdf, 2.
}

${ }^{121}$ Nathaniel Allen. "How Boko Haram has Regained the Initiative and What Nigeria Should Do to Stop It." Accessed 15 June 2020, from

https://warontherocks.com/2019/12/how-bokoharam-has-regained-the-initiative-and-what-nigeriashould-do-to-stop-it/ and "Boko Haram is 'defeated,' Nigeria insists, blaming international jihadists for ongoing insurgency" The Defense Post. July 31, 2019.

https://www.thedefensepost.com/2019/07/31/nigeriaboko-haram-defeated-iswap/ insurgency is rendering more and more people homeless. This has caused a hike in the number of internally displaced persons. Many of such people migrate to safer places. As observed in the review above, faith-based organizations are making efforts to transform the lives of these migrated displaced people in the society. While it is recommended that faith-based organizations should continue in their efforts to transform the lives of the displaced people and reintegrate them into the society, the Nigerian government should put in more efforts to safeguard the lives and properties of the citizens so that they, the people, will no longer become internally displaced persons or migrated displaced persons. There is need for further study on finding out more how faith-based organizations are responding to the plights of the people that are affected by conflicts and terrorism especially with documentary evidences.

\section{BIBLIOGRAPHY}

1. "2015 Humanitarian Needs Overview. Nigeria." $\begin{array}{llll}\text { Accessed } & 15 & \text { June }\end{array}$ http://reliefweb.int/sites/reliefweb.int/files/resour ces/HNO\%20Nigeria\%20\%20Final\%20version\%2015March\%202015.pdf.

2. "Anatomy of African Terrorism: Boko Haram: Nigeria's Homegrown Terror Network". World Policy Journal, Vol. 29, No. 4 (Winter 2012 / 2013).

3. "Baptist World Aid." Accessed June 10, 2016. https://www.bwanet.org/programs/baptist-world$\underline{\text { aid }}$

4. "Baptist World Alliance - Affirmations." Accessed 15 June 2020. http://bwanet.org/aboutus2/affirmations.

5. 'Boko Haram is 'defeated,' Nigeria insists, blaming international jihadists for ongoing insurgency" The Defense Post. July 31, 2019.

6. "Categories of Terrorist Groups." Accessed 15 June 2020. http://www.terrorismresearch.com/groups/categories.php

7. "Displaced Nigerians 'not alone,' Bapt. exec says." Accessed 15 June 2020. http://www.bpnews.net/44395/displacednigerians-not-alone-bapt-exec-says.

8. "Global Overview 2015: People internally displaced by conflict and violence." Accessed 27 February 2016, from http://www.internaldisplacement.org/assets/library/Media/20150 5-Global-Overview-2015/20150506-globaloverview-2015-en.pdf.

9. "IDMC Nigeria IDP Figures Analysis." Accessed 15 July 2016. http://www.internaldisplacement.org/sub-saharanafrica/nigeria/figures-analysis

10. "IDMC: Nigeria Internal Displacement as of December 2014." Accessed 23 June 2016. http://www.internal-displacement.org/subsaharan-africa/nigeria/2014/nigeria-internaldisplacement-as-of-december-2014. 
11. "Nigerian Baptist Convention Social Ministry" https://www.nigerianbaptist.org/departments/soci al-ministries-department/

12. "Nigerian Baptist leader castigates international community for ignoring terrorism in Nigeria." Accessed $15 \quad$ June 2020. https://www.bwanet.org/news/news-releases/452nigeria-terrorism.

13. "Report of the Resolution Committee of the Nigerian Baptist Convention-In-Session Held at Convention Ground, Ganmo, Ilorin, Kwara State, Nigeria between April 16-21, 2016" (Unpublished)

14. "Report on the Inter-Religious Tensions and Crisis in Nigeria." Accessed 15 June 2020. https://www.oikoumene.org/en/folder/docume nts-pdf/Report of Nigeria delegation.pdf.

15. "Report on the Inter-Religious Tensions and Crisis in Nigeria." Accessed 15 June 2020. https://www.oikoumene.org/en/folder/documentspdf/Report_of_Nigeria_delegation.pdf.

16. "Responding to the Crisis." Accessed 10 June 2016, from http://www.brethren.org/nigeriacrisis/response.h $\underline{t m l}$

17. "Southern Baptist Convention Basic Beliefs." Accessed $15 \quad$ June 2020. http://www.sbc.net/aboutus/basicbeliefs.asp.

18. "Statement on rights of internally displaced persons - World Council of Churches." Accessed $15 \quad$ June 2020. https://www.oikoumene.org/en/resources/docume nts/executive-committee/geneva-february2014/statement-on-rights-of-internally-displacedpersons.

19. "Statements of Faith of the Nigerian Baptist Convention." Accessed 15 June 2020. https://www.nigerianbaptist.org/aboutus/statements-of-faith/.

20. "The crisis in Nigeria, in 11 maps and charts Vox." Accessed 15 June 2020. http://www.vox.com/2014/5/13/5710484/bokoharam-maps-charts-nigeria

21. "The Royal Aal al-Bayt Institute for Islamic Thought." Accessed 15 June 2020. http://aalalbayt.org/en/index.html.

22. "The True Meaning of Jihad." Accessed 10 June 2016.

http://www.justislam.co.uk/product.php?products $i d=2$

23. "Trauma and Violence." Accessed 15 June 2020. http://www.samhsa.gov/trauma-violence/types

24. "WCC urges protection of refugees and displaced people from the Middle East - World Council of Churches." Accessed 15 June 2020. https://www.oikoumene.org/en/presscentre/news/wcc-urges-protection-of-refugeesand-displaced-people-from-the-middle-east.

25. "Welcoming Christ in Refugees and Forcibly Displaced Persons: Pastoral Guidelines." Accessed $15 \quad$ June 2020. http://www.vatican.va/roman_curia/pontifical_co uncils/corunum/corunum_en/pubblicazioni_en/Ri fugiati-2013-INGL.pdf.
26. "What is the World Council of Churches?" Accessed $15 \quad$ June 2020. https://www.oikoumene.org/en/about-us.

27. "What Makes a Baptist a Baptist: Beliefs, polity, ministries, practices, organizations, and heritage of Baptists." Accessed 15 June 2020. https://www.baptistdistinctives.org/resources/arti cles/what-makes-a-baptist-a-baptist/.

28. Adesoji, Abimbola O. "Between Maitatsine and Boko Haram: Islamic Fundamentalism and the Response of the Nigerian State." Africa Today, Vol. 57, No. 4 (Summer 2011).

29. Agbedo, Chris Uchenna, et al. "Sociopsychological deconstruction of fear of Boko Haram in Nigeria: The Nigerian media perspective." New Media and Mass Communication. Vol.16, 2013.

30. Ahmad, Hazrat Mirza Tahir. Murder in the Name of Allah. Amritsar: Printwell, 1990.

31. Akande Isaac, Babarinde. "Church Response to Religious Violence in Borno Baptist Association of Maiduguri Metropolitan Area." A Master of Arts in Theological Studies thesis submitted to the Nigerian Baptist Theological Seminary, Ogbomoso, June 2015.

32. Akanji, Israel Adelani. Towards A Theology Of Conflict Transformation: A Study Of Religious Conflict In Contemporary Nigerian Society. A PhD dissertation submitted to the University of Edinburgh in 2011.

33. Allen, Nathaniel. "How Boko Haram has Regained the Initiative and What Nigeria Should Do to Stop It." Accessed 15 June 2020, from https://warontherocks.com/2019/12/how-bokoharam-has-regained-the-initiative-and-whatnigeria-should-do-to-stop-it/.

34. American Psychological Association. "Managing traumatic stress: Coping with terrorism." Accessed $23 \quad$ June 2016. http://www.apa.org/helpcenter/terrorism.aspx

35. Azumah, John. "'Boko Haram' in Retrospect." Journal of African Christian Thought. Vol. 17, No. 1, June 2014.

36. Boer, Jan H. Christians and Muslims: Parameters for Living Together. Studies in Christian-Muslim Relations. Volume 8, Part 2. Belleville, Essence Publishing, 2009.

37. Brewer, John D. Peace Process: A Sociological Approach. Cambridge, Polity Press, 2010.

38. Campbell, John. "Boko Haram: origins, challenges and responses." Accessed 15 June 2020. https://www.ciaonet.org/attachments/27796/u ploads

39. Christian Aid Nigeria. "Reaching out: Emergency Humanitarian Relief Assistance project, Benue, Nigeria." Accessed 10 June 2016.

http://www.christianaid.org.uk/Images/Reachingout-humanitarian-report-July-2015.pdf.

40. Cohen, Roberta and Francis M. Deng (eds.). The Forsaken People: Case Studies of the 
Internally Displaced. Washington DC, The Brookings Institution, 1998.

41. Cohen, Roberta. "The Guiding Principles on Internal Displacement: An Innovation in International Standard Setting." Global Governance, Vol. 10, No. 4 (Oct.-Dec. 2004).

42. Comolli, Virginia. "Book Haram: Nigeria's Islamist Insurgency." In Christian Century March 2, 2016.

43. Conflict Barometer 2015. The Heidelberg Institute for International Conflict Research (HIIK) at the Department of Political Science, University of Heidelberg. Accessed 23 June 2016.

http://www.hiik.de/de/konfliktbarometer/pdf/Conf lictBarometer_2015.pdf

44. Cook, David. Boko Haram: A Prognosis (The James A. Baker III Institute for Public Policy of Rice University, 2011). Accessed 15 June 2020. https://www.bakerinstitute.org/media/files/Resear ch/535dcd14/REL-pub-CookBokoHaram121611.pdf.

45. Cordell, Karl and Stefan Wolff. Ethnic Conflict: Causes - Consequences - Responses. Cambridge, Polity Press, 2010.

46. Danielsen, Gert. "Meeting Human Needs, Preventing Violence: Applying Human Needs Theory to the Conflict in Sri Lanka." USAL, September 2005.

47. Deng, F.M. "Internally Displaced Persons: An interim report of the UN Secretary General on protection and Assistance, New YorK: Un Dept. for Humanitarian Affairs, Washington, D.C., U.S.A; Francis M. Deng (1999). Guiding Principles on Internal Displacement." The International Migration Review, Vol. 33, No. 2 (Summer, 1999).

48. Division on Freedom and Justice of the Baptist World Alliance. Global Human Rights Contacts. Accessed $15 \quad$ June 2020. http://www.bwanet.org/images/pdf/hrorganizations.pdf.

49. Dorrell, Oren. "Boko Haram: Facts, History, Leaders, and Origins of the Terrorist Group." Accessed 15 June 2020. http://www.huffingtonpost.com/2014/05/09/b oko-haram-facts-history $n$ 5295563.html

50. Eniola, Titi. "Social Impact on Victims of Terrorist Attack: Nigerian Girl Education." A paper presented at a conference organized by Omoniyi Ogodo Bach at Saarbrucken-Am Staden, Germany on October 8, 2015.

51. Enwereji, E.E. Assessing interventions available to internally displaced persons in Abia state, Nigeria, Libyan Journal of Medicine, 4:1, 23-24. 2008. Accessed 15 June 2020. https://doi.org/10.3402/ljm.v4i1.4800.

52. Gish, Peggy. "NIGERIA: Church of the Brethren family cares for fifty-two people displaced by Boko Haram." Accessed 15 June 2020. http://www.cpt.org/cptnet/2015/05/27/nigeriachurch-brethren-family-cares-fifty-two-peopledisplaced-boko-haram
53. Hampton, Janie (ed.). Internally Displaced People: A Global Survey. London, Earthscan Publications Ltd, 1998.

54. Helmick, S.J, Raymond G. "Does Religion Fuel or Heal in Conflicts?" In Helmick, S.J., Raymond G. and Rodney L. Petersen (eds.). Forgiveness and Reconciliation: Religion, Public Policy \& Conflict Transformation. Radnor, Templeton Foundation Press, 2001.

55. Hill, Jessie and Adam F. Kimney. Sacred Violence: Religion and Terrorism. Cleveland, Ohio: Case Western Reserve University, 2008. Accessed June 23, 2016. http://scholarlycommons.law.case.edu/cgi/viewco ntent.cgi? article $=1316 \&$ context $=$ jil

56. Idahosa, Osaretin. "Boko Haram and the Nigerian State: A Different Perspective." Glocalism: Journal of Culture, Politics and Innovation. $\quad 2015, \quad 3, \quad$ DOI: 10.12893/gjcpi.2015.3.5.

57. Kälin, Walter. "Guiding Principles on Internal Displacement: The Way Ahead." Proceedings of the Annual Meeting (American Society of International Law), Vol. 102 (APRIL 9-12, 2008).

58. Knezevic, Branis and Seth Olson. Counseling People Displaced by War: Experiences of Refugees from the Former Yugoslavia. Professional Counselor. Vol. 4, No. 4, 2014.

59. Liman, A. "Boko Haram: Why the Northerners Believe Jonathan is Guilty." Accessed 8 June 2016, from http://leadershing/features/396929/boko-haramnortherners-believe-ionathan-guilty.

60. Maiangwa, B., et al. “'Baptism by Fire': Boko Haram and the Reign of Terror in Nigeria." Africa Today, Vol. 59, No. 2 (Winter 2012).

61. Malik, Ibrahim. "Jihad - Its Development and Relevance." The Palestine-Israel Journal. Vol.1 No.2 1994 / Religion and Politics. Accessed 15 June

2020. http://www.pij.org/details.php?id=741

62. Martin, Gus. Essentials of Terrorism: Concepts and Controversies. Second Edition. Thousands Oaks, Sage Publications, Inc., 2011.

63. Mulders, Arne. Summary of the Research Report 'Crushed But Not Defeated, the Impact of Persistent Violence on the Church in Northern Nigeria'. Open Doors International, February 2016.

64. Oduah, Chika. "A holy burden: Nigerian religious groups aid Boko Haram victims." Accessed $15 \quad$ June 2020. http://america.aljazeera.com/articles/2015/2/26/c arrying-a-holy-burden-in-nigeria.html

65. Oduwole, Tajudeen A. and Adebayo $O$. Fadeyi. "Issues of Refugees and Displaced Persons in Nigeria." Journal of Sociological Research. ISSN 1948-5468 2013, Vol. 4, No. 1.

66. Ogunmade, Omololu. "How Boko Haram Entered Nigeria." Accessed 27 February 2016.

http://www.thisdaylive.com/articles/howboko-haram-entered-nigeria/216981/ 
67. Oladimeji, SO. Faith, Stewardship and Security: Christians Collaborating with God to Handle Security Matters. Ibadan, Nigerian Baptist Convention, 2013.

68. Owolade, Femi. "Boko Haram: How a Militant Islamist Group Emerged in Nigeria." Accessed 15 June 2020. http://www.gatestoneinstitute.org/4232/bokoharam-nigeria

69. Ramiah, Jocelynn. "The Boko Haram Insurgency and The Hardships Faced by Its Victims." Ifriqiya - Africa Research and Analysis. Volume 1, Number 8 October 20, 2015.

70. Rausch, C. C. "Fundamentalism and Terrorism." Journal of Terrorism Research, Volume 6, Issue 2-May 2015.

71. Samu, Maiwa'azi Dandaura. "Boko Haram Conflict Research/Anaysis \& Management Preventive Counterterrorism and Sustainable Peacebuilding: Nigeria and Boko Haram Case Study." Center for Justice and Peacebuilding, Eastern Mennonite University, USA. Accessed 15 June 2020.

https://www.academia.edu/6777526/BOKO_HAR AM_CONFLICT_RESEARCH_ANAYSIS_and_M ANAGEMENT_PREVENTIVE_COUNTERTERR ORISM_AND_SUSTAINABLE_PEACEBUILDIN G NIGERIA AND BOKO HARAM CASE STU $D Y$.

72. Sandler, Todd. "Terrorism and Counterterrorism: An Overview." Oxford Economic Papers, 2014. Accessed 23 June 2016. http://oeoxfordjournals.org/content/early/2014/1 1/05/oegpu039.full.pdf+html.

73. Sergie, Mohammed Aly and Toni Johnson. "Nigeria's Boko Haram and Ansaru. Council on Foreign Relations." Accessed June 9, 2016. http://www.cfr.org/nigeria/boko-haram/p25739

74. Sewakpo, H. M. "The Relationship Between the Pre-Conversion Character of Paul in Acts 8-9 and the Nigerian Boko Haram Insurgence: Implications for Peaceful Coexistence in Nigeria." In Ayantayo, Jacob K. and Samuel Adetunji Fatokun (eds.) (2015). Religion and Security Issues: Proceedings of 2013 Biennial International Religious Studies Conference. Religious Studies Series, Volume 5. Ibadan, Department of Religious Studies, University of Ibadan, Ibadan.

75. Silberman, Israela. "Religious Violence, Terrorism, and Peace: A Meaning-System Analysis." In Raymond F. Paloutzian and Crystal L. Park (eds.). Handbook of the Psychology of Religion and Spirituality. New York: The Guilford Press, 2005

76. Suberu, Ibrahim. "Martyrs or Terrorists: Suicide Bombing in Islamic Hermeneutics. Ilorin Journal of Religious Studies. Vol. 5 No. 1. 2015.

77. Terwase, Isaac Terungwa, et al. "The Psychological Trauma on Boko Haram Victims in Nigeria: Conflict Resolution Perspective." Mediterranean Journal of Social Sciences. Vol 6 No $6 \quad$ S4 MCSER Publishing, Rome-Italy December 2015.
78. The Institute for Economics and Peace. Global Terrorism Index Report 2014: Measuring and Understanding the Impact of Terrorism. Accessed June 23, 2016 from http://www.visionofhumanity.org/sites/default/file s/Global\%20Terrorism\%20Index\%20Report\%20 2014 0.pdf.

79. Ukanah, Philip Oluwole. In God's Name: The Story of Nigeria's Religious War and Its Brutal Killings. Ibadan, Divine Press, 2011.

80. UN High Commissioner for Refugees. Handbook for the Protection of Internally Displaced Persons. Accessed 15 June 2020. http://www.unhcr.org/4c2355229.pdf.

81. Wellman, James and Kyoko Tokuno. "Is Religious Violence Inevitable?". Journal for the Scientific Study of Religion. 43 (3). Accessed 15 June 2020. https://doi.org/10.1111/j.14685906.2004.00234.x.

82. Wilson, Lynette. "Colombia Church stands with internally displaced people Episcopal Church." Accessed $15 \quad$ June 2020. http://www.episcopalchurch.org/library/article/c olombia-church-stands-internally-displacedpeople 